\title{
Weichselian Juniperus in the Frøslev alluvial fan (Denmark)
}

\author{
ELSE KOLSTRUP and KENT HAVEMANN
}

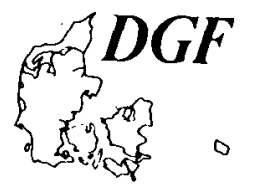

\begin{abstract}
Kolstrup, E. \& Havemann, K.: Weichselian Juniperus in the Frøslev alluvial fan (Denmark). Bull. geol. Soc. Denmark, vol. 32, pp. 121-131. Copenhagen, September, 4th, 1984. https://doi.org/10.37570/bgsd-1983-32-08

In the southern part of Jutland pieces of Juniperus wood have been found over long stretches in a trench dug for a Danish gas pipe line system. Radiocarbon-dating, comparison with palaeobotanical records known from other localities, and the stratigraphical sequence in the area, point to a probable age of between the Brørup/Odderade interstadial(s) and ca. 45.000 years B.P.

The morphology of the alluvial fan near Frøslev and its stratigraphy makes it reasonable to assume that the fan has not been affected by the Middle Weichselian ice and its meltwater streams.
\end{abstract}

Else Kolstrup, Danmarks geologiske Undersøgelse, Thoravej 31, DK-2400 København NV, Denmark. Kent Havemann, Dønnerupvej 12A, DK-4450 Jyderup, Denmark, June 6th, 1983.

During the construction of a gas pipe line system near Frøslev in southern Jutland charred fragments of wood were found in several localities (fig. 2). The preliminary conclusion in the field was that the pieces of wood might be of Middle or maybe Early Pleniglacial age (van der Hammen 1971, van der Hammen, Maarleveld, Vogel \& Zagwijn 1967) (Middle Weichselian: Doppert, Ruegg, van Staalduinen, Zagwijn \& Zandstra 1975). Only a few organic deposits from the Middle and Early Pleniglacial are known in Denmark (Houmark-Nielsen \& Kolstrup 1981, Lykke-Andersen 1981) and it was therefore decided to have some samples radio-carbon dated and that the second author would make wood anatomical investigations of pieces from various localities.

\section{Geological outline}

In fig. 1 the geology of the surroundings of the southern $13 \mathrm{~km}$ of the gas pipe line trench is given according to Hansen (1965), and in fig. 2 contour lines with an interval of 5 meters are shown for the same area.

It can be seen that the area contains part of a large fan with a rather flat surface which slopes gently towards the west and northwest, and that the main types of surface sediments are eolian sand, fresh-water sand, and fresh-water gravel.
For conveniance this fan is called the Frøslev alluvial fan or the Frøslev fan. Newer field investigations have revealed that along the gas pipe line trench the eolian deposits of Hansen's map are of the Younger Cover Sand type, and part of the fresh-water deposits are of the Older Cover Sand type (Kolstrup in press, Kolstrup \& Jørgensen 1982). The fresh-water gravel of Hansen along the trench usually consists of a mixture of sand and gravel which is involuted (cryoturbated) in many places. In the contour line map of fig. 2 the revised geology is outlined together with localities where wood has been seen in the trench, which is approximately 1.8 meters deep.

\section{Stratigraphical outline}

The upper part of the stratigraphical sequence found in the pipe line trench in the Frøslev fan is given in fig. 3.

The periglacial phenomena, mainly cryoturbations, extend downward from the sand and gravel layer below the Frøslev gravel bed, and it is therefore difficult to unravel a general lithostratigraphy for the sediments underlying the sequence shown in fig. 3. It is noted, however, that wood fragments are found at a lithostratigraphic level somewhat below the lower sand and gravel of fig. 3. As the trench is less than two meters deep, it is 


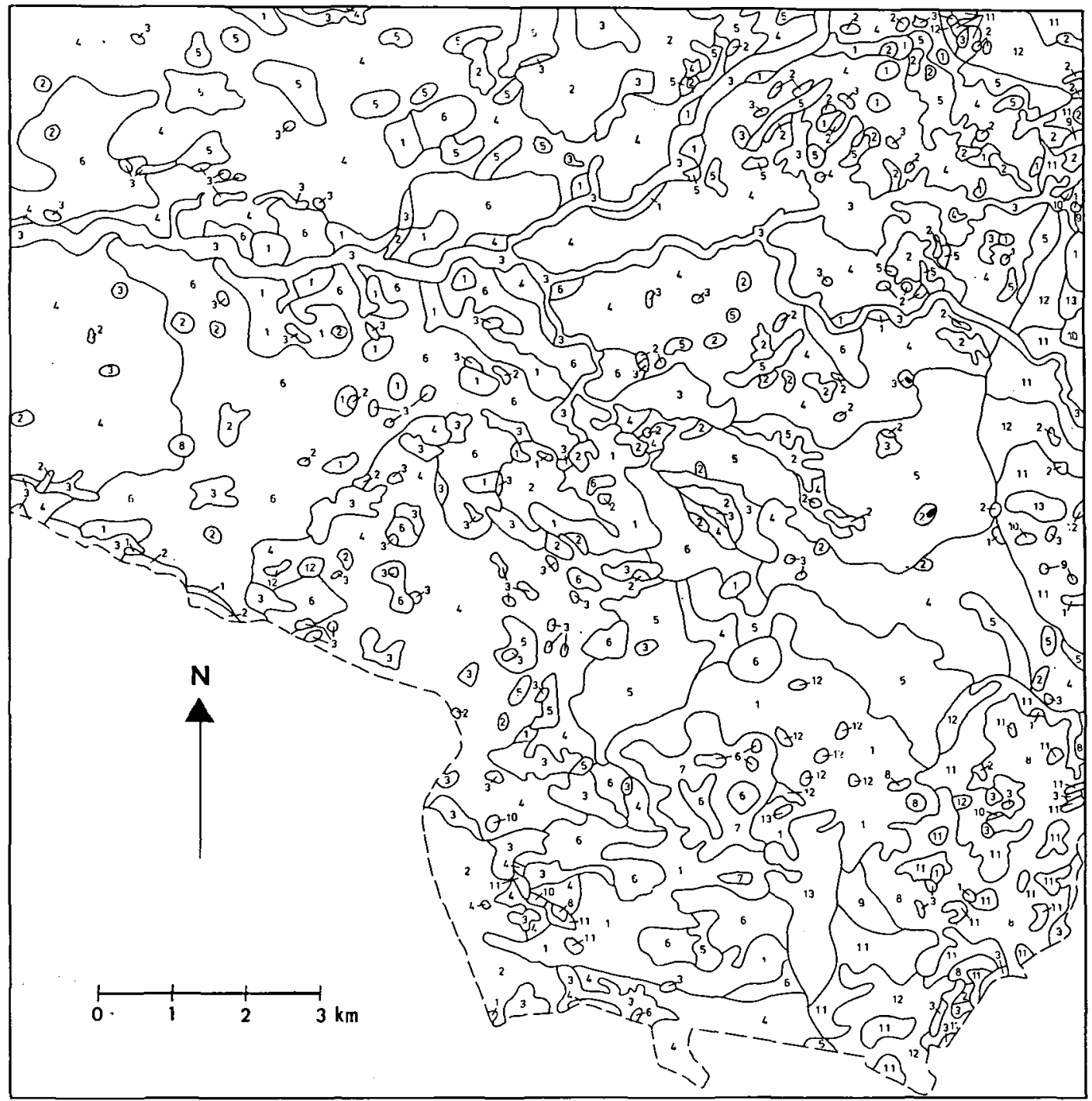

\begin{tabular}{|c|c|c|c|}
\hline \multicolumn{3}{|c|}{ POSTGLACIAL DEPOSITS } & GLACIAL DEPOSITS \\
\hline 1$)$ & eolian sand & 81 & clayey till \\
\hline 21 & peat & $9 i$ & sandy till \\
\hline 31 & fresh-water mud,-clay & 101 & gravelly till \\
\hline & - sand, and-gravel & 111 & layered sand \\
\hline & LATE-GLACIAL DEPOSITS & 121 & layered gravel \\
\hline 41 & fresh-water sand & 131 & eolian sand over \\
\hline 51 & fresh-water gravel & & layered sand \\
\hline & $\begin{array}{l}\text { eolian sand over } \\
\text { fresh-water sand }\end{array}$ & & \\
\hline 71 & eolian sand over fresl & ara & \\
\hline
\end{tabular}

Fig. 1. Outline of the geology around the southern $13 \mathrm{~km}$ of the gas pipe line trench according to Hansen (1965). Reproduced with permission of the Geological Survey of Denmark. 

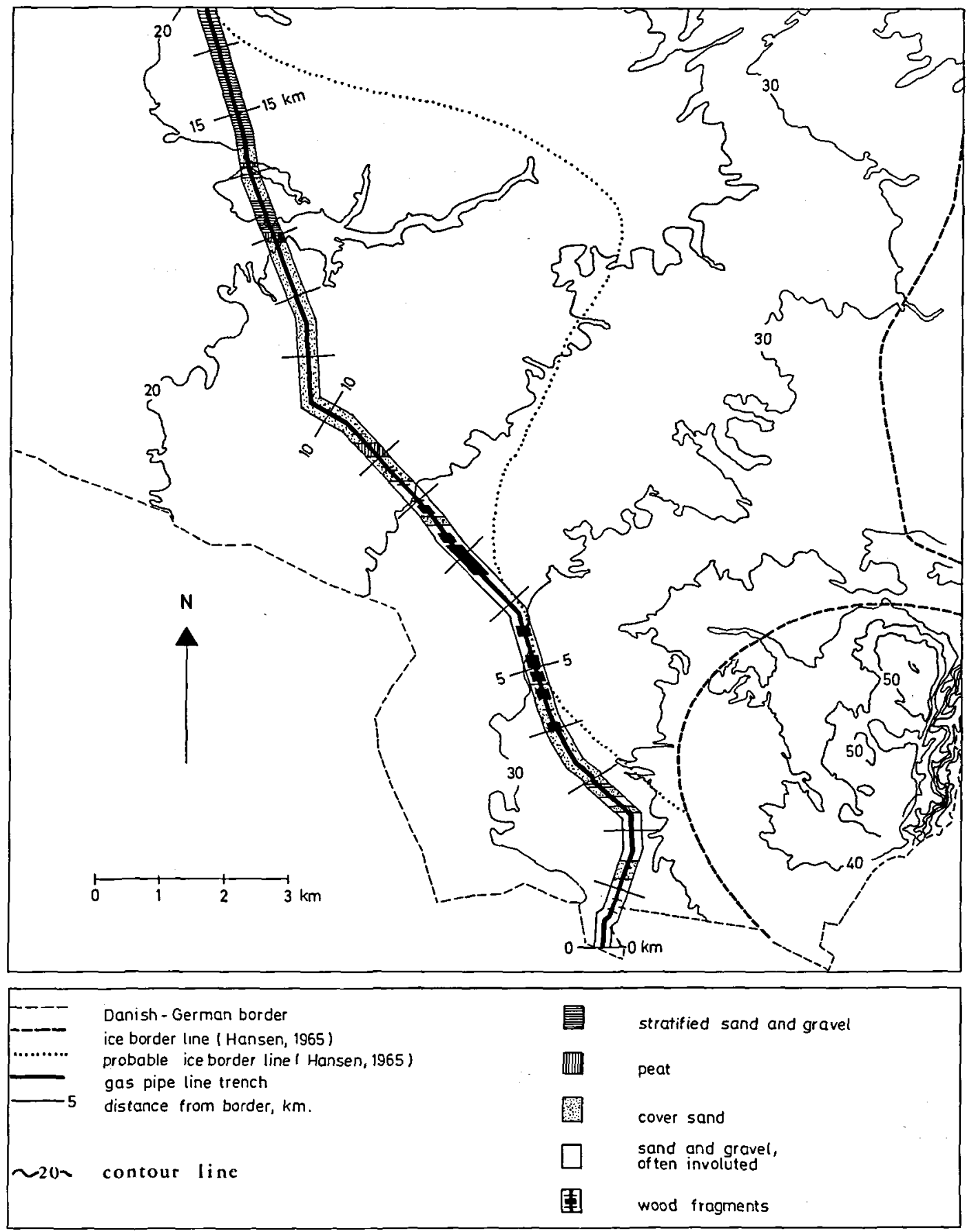

Fig. 2. Map of the same area as fig. 1. Contour lines with an interval of 5 meters, revised geology, and wood occurrences are shown. The contour lines are reproduced from map 1211 IV, 1:25.000 with permission of Geodætisk Institut (A 83). 


\begin{tabular}{|c|c|}
\hline LITHOSTRATIGRAPHY & CHRONOSTRATIGRAPHY \\
\hline SOIL OR PEAT & HOLOCENE \\
\hline YOUNGER COVER SAND II & LATE DRYAS \\
\hline LOAMY SAND OR PEAT & ALLERøD \\
\hline YOUNGER COVER SAND I & EARLIER DRYAS \\
\hline LOWER LOAMY BED & BøLLING \\
\hline OLDER COVER SAND II & \multirow{5}{*}{ PLENIGLACIAL } \\
\hline \begin{tabular}{l|l} 
FRøSLEV & FRØSLEV GRAVEL BED \\
\cline { 2 - 3 } &
\end{tabular} & \\
\hline \begin{tabular}{l|l} 
COMPLEX & (periglacial processes) \\
SAND AND GRAVEL
\end{tabular} & \\
\hline OLDER COVER SAND I & \\
\hline $\begin{array}{l}\text { WIND POLISHED PEBBLES } \\
\text { SAND AND GRAVEL }\end{array}$ & \\
\hline
\end{tabular}

Fig. 3. Outline of the stratigraphy in the Frøslev alluvial fan.

therefore not surprising that the wood pieces are most frequently recorded where the eolian sand cover is thin or absent (fig. 2).

\section{The wood fragments}

Field observations

Pieces of wood, charred wood, and charcoal were found almost continuously over long stretches in the pipe line trench (fig. 2). The layer in which they were recorded was often involuted (fig. 4) and it was therefore often disrupted. Mostly the pieces were found in a fluviatile unit of sand and gravel; sometimes they were even concentrated on the fore-sets of ripples (fig. 5) and in single localities two horizons, one above the other,

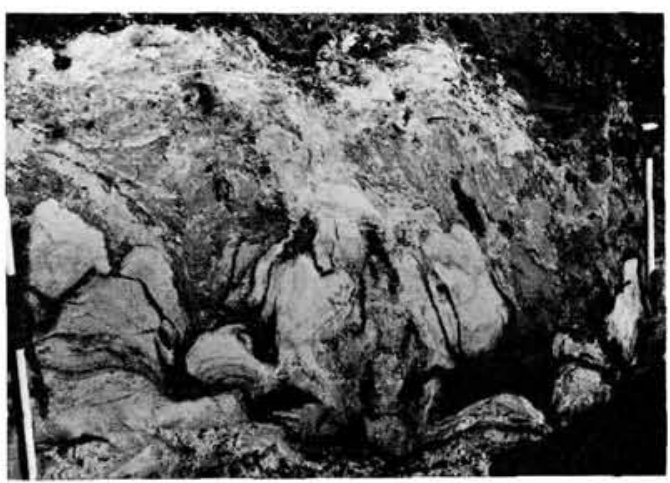

Fig. 4. Involuted sediment of loam, sand, and gravel. The black parts contain wood fragments $(\mathrm{km} \mathrm{0.450)}$. The visible part of the spade is ca. 1 meter long.

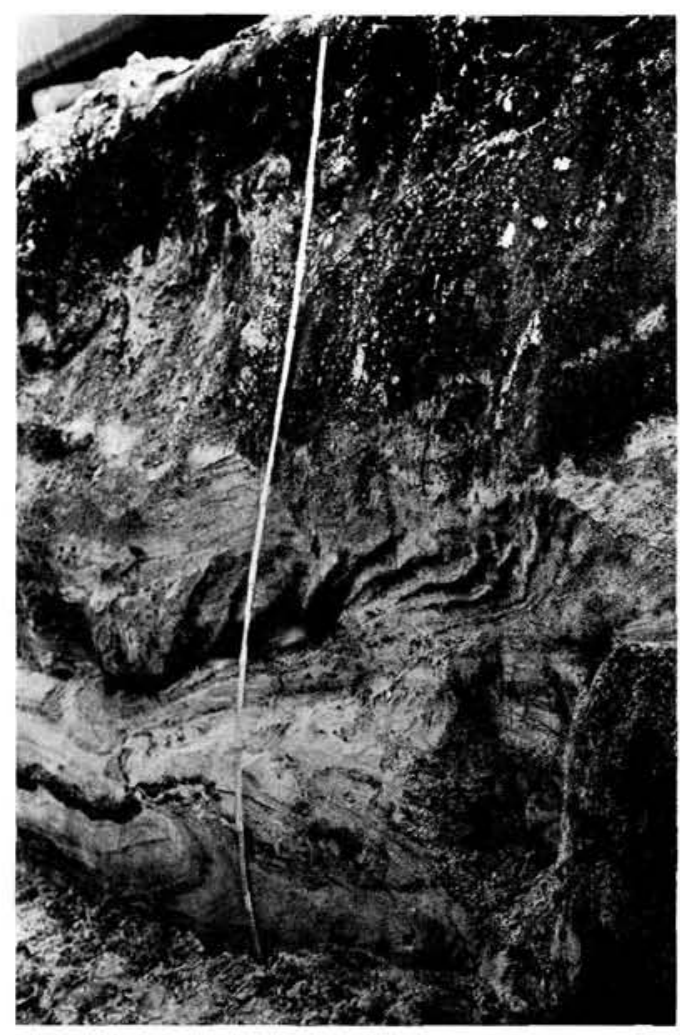

Fig. 5. Slightly involuted sediment with wood fragments in two horizons (black) and wood pieces on fore-sets in the upper horizon. The ruler is two meters long ( $\mathrm{km} \mathrm{7.030)}$.

contain wood pieces (fig. 5). In most sites the wood is dispersed in a sandy gravelly layer where its concentration may vary from moderate to rather low, but in other places a layer more than four $\mathrm{cm}$ thick of almost pure wood material is found. This evidence shows that, in most places, the wood has been transported to the present sites by water. In two sites the wood may be in primary position, namely at $\mathrm{km} 5.085$ and $\mathrm{km}$ 8.715 from the Danish-German border. In both these localities small pieces of wood are restricted to a layer a few centimeters thick which shows faint bioturbation, and larger pieces of wood are arranged vertically from a few centimeters below to a few centimeters above the layer containing the wood (figs 6 and 7).

From these figures it can also be seen that no periglacial phenomena extend downward from the layers immediately above the layer containing the wood. 


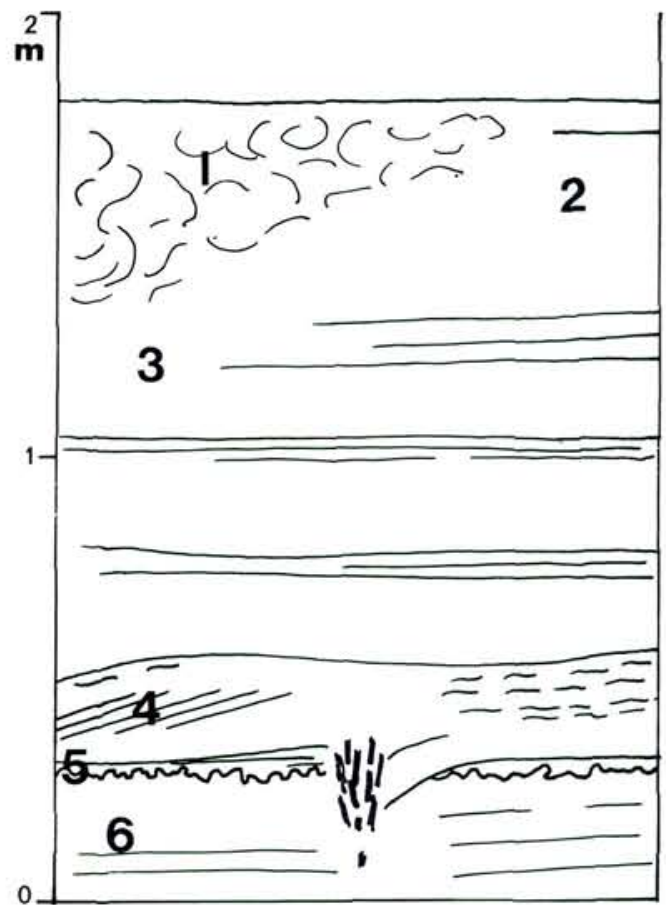

Fig. 6. Profile sketch of site at $\mathrm{km} 8.715$ with wood fragments probably in situ (black vertical parts in lower part of profile). The top soil is removed. (1) involuted sand, (2) indistinct, horizontal layers of 75-125 $\mu \mathrm{m}$ sand alternating with layers of $150-250 \mu \mathrm{m}$ sand, dotted gray and ochre, individual layers wellsorted, coarser grains well-rounded and polished, eolian of Older Cover Sand type, (3) as (2) but light ochre, (4) gray, wellsorted, well- to subrounded sand, $125 \mu \mathrm{m}$ dominant, eolian or fluvial?, (5) dark gray, $105 \mu \mathrm{m}$, well-sorted slightly bioturbated sand layer with small pieces of wood, incipient soil development in eolian sand, and (6) indistinctly horizontally layered sand with dominance around $105 \mu \mathrm{m}$, well-sorted, subroundedsubangular, larger grains polished, eolian.

\section{Macroscopic description}

The wood fragments are between less than one millimeter to approximately 10 centimeters long and up to 4 centimeters thick. Circular or partly circular sections have not been found and it is therefore concluded that the diameter of some pieces must originally have been more than $4 \mathrm{~cm}$.

The state of preservation ranges from very soft (can be squeezed out with the fingers) to hard (a knife is necessary to cut it even when wet or moist). Some pieces could be broken into long flakes while others are massive.

\section{Microscopical investigation}

Microscopical investigations have been made on wood pieces from sites at $\mathrm{km} 0.750,3.945,4.285$,
$4.405,5.350,7.110$ and 8.715 . Between five and ten of the best preserved pieces, suitable for wood identification were selected from each sample. Each piece of wood was cleansed in distilled water and examined under a binocular microscope with low magnification in order to reveal the main structures. Then transverse sections (TS), radial longitudinal sections (RLS), and tangential longitudinal sections (TLS) were cut with a razor blade. Each section was placed in glycerine on a slide ready for identification.

The diagnostic features are:

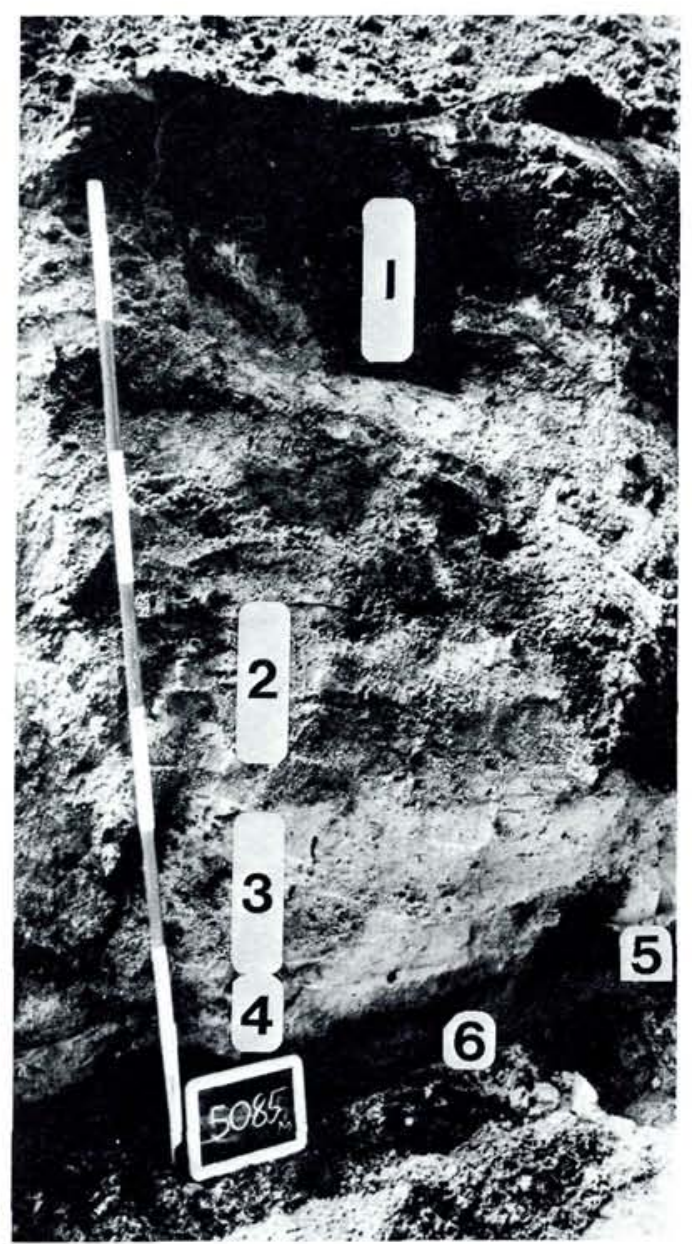

Fig. 7. Photo of profile at $\mathrm{km} 5.085$ with wood fragments probably in situ (black part in right hand lower part of profile). (1) involuted fine sand, sand, and gravel, (2) medium sorted, $375 \mu \mathrm{m}$ sand with a little gravel, dark ochre, fluviatile, (3) as (2) but gray-light ochre, (4) light gray, well-sorted, well to subrounded $105 \mu \mathrm{m}$ sand, eolian, (5) as (4) but gray with small pieces of wood and faint bioturbation, (6) as (4). The topsoil is removed. The units of the ranging pole are $20 \mathrm{~cm}$ long. 

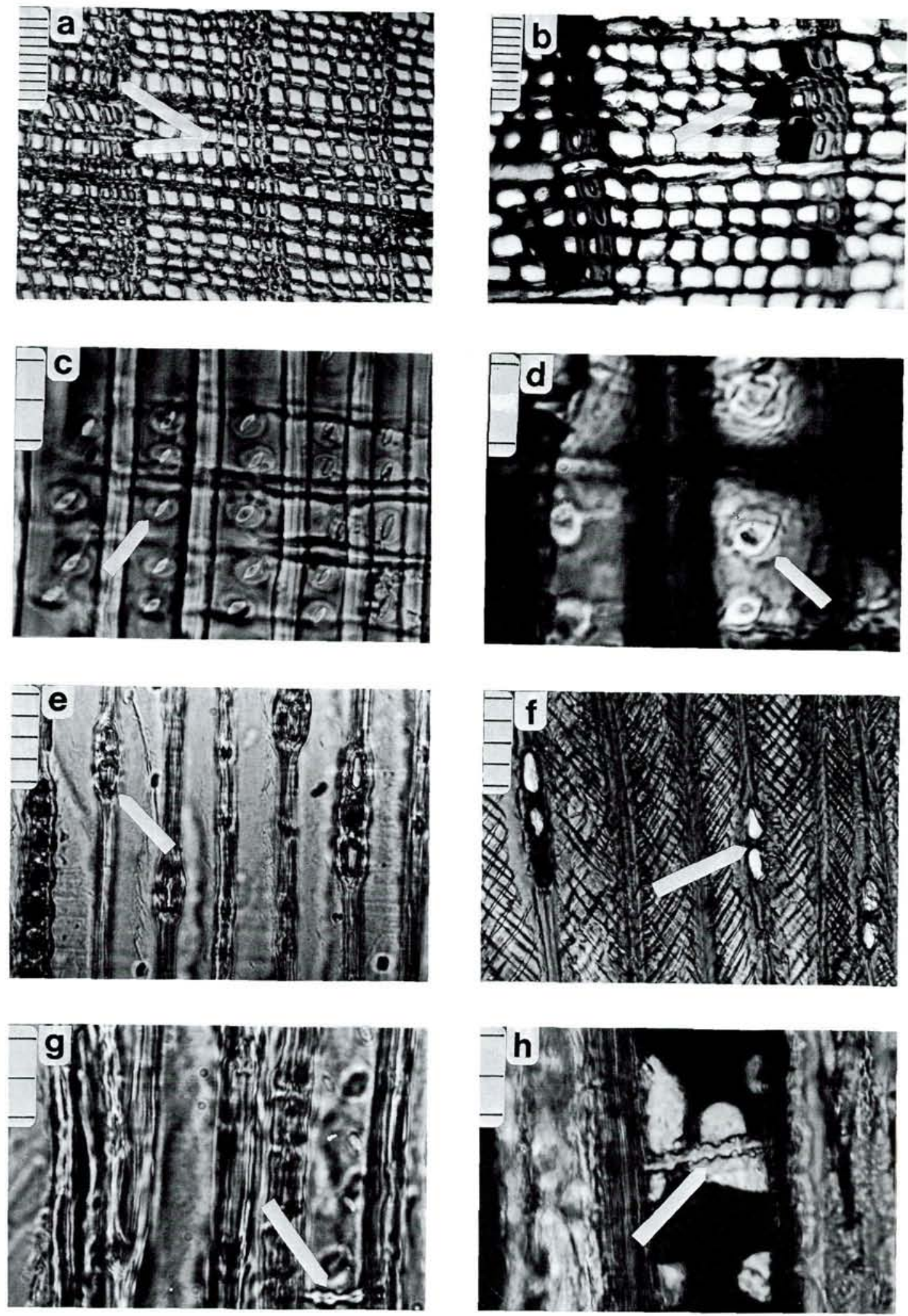
TS: No resin ducts; parenchyma conspicuous in the latewood; rather narrow annual rings. Fig. $8 b$.

RLS: Cross field pits of cupressoid type; rays homocellular; cross field pits mostly vertically one above another, 1-4 in each cross field; horizontal walls of parenchyma cells either thin and smooth or with nodose thickenings. Fig. $8 d, h$.

TLS: Low uniseriate rays. Fig. 8f.

From these characteristics it was decided that the wood remains represent Juniperus sp. (compare e.g., Greguss 1955, Schmidt 1941). As identification of the various species of Juniperus is almost impossible a further distinction was not attempted.

$\mathrm{Re}$ TS: The widths of the annual rings were found to vary between $0.06 \mathrm{~mm}$ and $0.48 \mathrm{~mm}$. In one piece five consecutive annual rings each 0.07 $\mathrm{mm}$ wide were found next to a similar number which were $0.33 \mathrm{~mm}$ each.

Kjeld Christensen, Nationalmuseet, kindly investigated the widths of annual rings in recent Juniperus wood from various localities.

In a sample from Mols Bjerge (Denmark) he counted 71 rings with a mean annual width of $0.42 \mathrm{~mm}$. A sample from Hemsedal (Norway), altitude $300-500$ meters, had 115 rings with a mean width of $0.4 \mathrm{~mm}$. A second sample from the same Norwegian area, at an altitude of 1200 1300 meters, had ca. 500 rings. This sample seems to originate from stem wood close to the ground. The mean widths along the longest radius are in hundred year intervals: years 1-100: $0.26 \mathrm{~mm}$, years $100-200: 0.38 \mathrm{~mm}$, years 200 300: $0.30 \mathrm{~mm}$, years $300-400: 0,19 \mathrm{~mm}$, and years 400-500: $0.33 \mathrm{~mm}$. Along the shortest radius the mean annual width is ca. $0.16 \mathrm{~mm}$. A sample from 2100 meters altitude in the Zellertal in Tyrol had 40 annual rings with a mean of $0.13 \mathrm{~mm}$. Measurements made by Kihlman (1890) in Russian Lappland gave widths between $0.15 \mathrm{~mm}$ and $0.39 \mathrm{~mm}$.
However, the spring-wood in most of the microscopic rings of the fossil wood was compacted and a measure of the original ring width was therefore impossible to establish. The compaction may be due to a combination of decay and drying out of the wood, and pressure from the overlying sediments.

Re RLS: The samples showed various stages of decay. Thus it was very difficult to establish proof of the important diagnostic feature of the cross field pits, because the tracheidal secondary wall in some samples was decomposed so much that there was no sign of bordered pits. These walls showed innumerable cracks. Fig. $8 \mathrm{c}, \mathrm{d}, \mathrm{f}$.

Re TLS and RLS: The diagnostic features indicated that there was Juniperus wood in all samples. There was, however, a quantitative difference between the wood elements. In the samples with the larger elements, the parenchyma cells were shorter and thicker than in other samples. It can not be decided whether this difference can be ascribed to internal variations within the same tree or species (stem wood, branch wood, root wood, or juvenile wood), or whether it represents the presence of more than one species.

The majority of the identified wood was Juniperus. The samples contained single pieces of deciduous wood as well, but due to advanced decay it was only possible to identify it as either Alnus or Betula.

The abundance of Juniperus fragments in this part of Denmark and the two probable in situ sites strongly suggest that it once grew on the Frøslev alluvial fan.

\section{Dating of the wood}

A comparison between the lithostratigraphies from the Frøslev fan and that of the cover sand areas in The Netherlands (e.g., van der Hammen et al. 1967, Doppert et al. 1975) makes it reason-

Fig. 8. Diagnostic features of recent Juniperus compared to the sampled wood. a: Transverse section of recent Juniperus communis L. b: Transverse section of sampled wood. Early wood not compressed. Note the rather narrow annual rings and the parenchyma cells, filled with dark substance (arrows). c and d: Radial longitudinal sections of recent Juniperus (c) and of sampled wood (d) showing cupressoid pits (arrows) in the cross field between horizontal ray cells and vertical tracheids. $e$ and $\mathrm{f}$ : Tangential longitudinal sections of recent Juniperus communis L. (e) and of sampled wood (f) showing low, uniseriate rays (arrows). Note the many cracks in the cell walls of the sampled wood due to decay. $g$ and $h$ : Tangential longitudinal sections of recent Juniperus communis ( $\mathrm{g}$ ) and of sampled wood (h) showing nodose thickenings of the horizontal walls of the parenchyma cells (arrows). Each unit in the scales in the upper left corners is $0.01 \mathrm{~mm}$ long. 
able to assume that the Juniperus pieces are of Middle Pleniglacial age or maybe older.

If the wood fragments date from the Eemian or an Early Weichselian interstadial it might be expected by comparison with macro-remains and pollen diagrams known from other localities that conifer wood remains would include at least some of the species of Abies, Picea, Pinus, Larix, and Taxus (Andersen 1961, Averdieck 1967, Jessen \& Milthers 1928, Mamakowa, Mook \& Srodoń 1975, Zagwijn 1961; compare also Menke 1976). But the microscopical investigations show that Juniperus was probably the only or by far the most dominant conifer in the area.

If the Juniperus growth was older than Early Weichsel and Eem it might be expected either that macro-remains from these periods would be represented among the wood as well, or that indications for a warmer period would be present at a stratigraphic level above the Juniperus wood horizon; but nowhere in the pipe line trench were peat layers or (part of) soils found between the Juniperus layer and the cover sand sequence outlined in fig. 3.

Radio-carbon datings have been made on samples from $\mathrm{km} 5.350\left(54^{\circ} 50^{\prime} 48^{\prime \prime} \mathrm{N}, 9^{\circ} 16^{\prime} 22^{\prime \prime} \mathrm{E}\right), \mathrm{km}$ $7.110\left(54^{\circ} 51^{\prime} 32^{\prime \prime} \mathrm{N}, 9^{\circ} 15^{\prime} 21^{\prime \prime} \mathrm{E}\right)$, and $\mathrm{km} 8.715$ $\left(54^{\circ} 52^{\prime} 11^{\prime \prime} \mathrm{N}, 9^{\circ} 14^{\prime} 24^{\prime \prime} \mathrm{E}\right)$ by the ${ }^{14} \mathrm{C}$-Laboratory in Groningen, The Netherlands.

The results of the datings are:

GrN-11103 Krathuse

$>42.000$ B.P.

GrN-11104 Sofiedal 1

(km 5.350)

$>49.000$ B.P.

GrN-11105 Sofiedal 2

(km 7.110)

$47.000+5300$ B.P.
-3200

(km 8.715)

A comparison with other localities in the northwest European cover sand area reveals that no Juniperus fragments younger than Brørup/ Odderade and older than ca. 45.000 B.P. have yet been found elsewhere. A number of pollen sequences represent the Moershoofd Interstadial Complex (van der Hammen 1971, Kolstrup \& Wijmstra 1977, Odgaard 1982, Zagwijn 1974) but only low percentages of Juniperus pollen are found. Furthermore it is not known which other plants were present at the time of Juniperus growth near Frøslev. Even though Juniperus may have been fairly abundant there must have been other plants at that time as well. But only the more resistant conifer wood is preserved well enough to allow identification.

The low percentages of Juniperus in the pollen diagrams representing the Moershoofd Interstadial Complex might argue against the wood fragments being of this age. On the other hand the palaeovegetation may have been different in various areas at that time, and it is possible that pollen diagrams from moist and wet depressions almost exclusively represent pollen sedimentation from the local vegetation.

From the radio-carbon datings and the above considerations it seems reasonable to assume that Juniperus grew on the alluvial fan near Frøslev after the Brørup/Odderade interstadial(s) and before 45.000 years B.P., possibly during the early part of the Moershoofd Interstadial Complex.

\section{Palaeoenvironment}

The environmental conditions are rather more difficult to unravel. As it is unknown which other plants grew near Frøslev at that time no information for a reconstruction of the growing conditions can be gained from this source, and furthermore it is not known which Juniperus species the wood fragments originate from.

The best preserved annual rings were found in flakes of wood and it was therefore not possible to obtain a transverse section with a large number of consecutive rings that might reveal indications of the environmental conditions. And since the spring-wood was often compressed a comparison with recent Juniperus ring widths cannot be very precise. The few well preserved series, however, did not suggest extreme growth conditions and it was noted that the rings of the fossil wood were not radically different from the recent samples mentioned above.

As mentioned above, sections from some of the samples showed quantitative differences in the size of the cells. Unfortunately the material does not allow inferences as to whether this is due to external influences (more favourable growing conditions, e.g., milder or moister climate) or internal conditions.

The state of preservation of the wood frag- 
ments suggests that they have probably been covered by ground water during most of the time since deposition, but this conclusion does not help to reveal the conditions during the time in question either.

A slight indication of dry conditions might be suggested by the presence of eolian deposits below and on the wood pieces in the two probable in situ sites (compare also the lower part of the Moershoofd Interstadial Complex in The Netherlands; Kolstrup \& Wijmstra 1977), but drought need not be the reason for the accumulation of these deposits.

All in all it seems that conclusions concerning the environmental conditions during the Juniperus growth cannot be made until more evidence is available.

On the other hand, the co-occurrence of wood pieces and charcoal might provide a plausible explanation for the termination of the Juniperus growth as it might indicate that a fire swept over the area and burned the outer parts of the Juniperus while the central parts were left undamaged but unable to regenerate.

\section{Palaeogeographic implications}

The Frøslev alluvial fan (which continues southward into Germany) constitutes a separate fan of the Tinglev outwash plain. The geological maps of this area (Hansen 1965, Milthers 1948) suggest that ice covered at least the eastern part of this fan during the Weichselian (fig. 2).

A comparison between the stratigraphy in the Frøslev fan and the rest of the Tinglev outwash plain shows that the stratigraphical sequences are similar from the Frøslev gravel bed upwards. Below that level fluvial sand and gravel in primary position is found in the Tinglev area north of the Frøslev fan while the Frøslev fan has a rather complex stratigraphy comparable to Dutch sequences.

It is difficult to assess the thickness of fluviatile accumulations in the Frøslev fan after the Juniperus growth because the wood fragments are usually incorporated in these deposits. However, the concentration of wood pieces at a certain level suggests that the wood has probably not been reworked repeatedly and it seems, therefore, that fluvial deposits younger than the
Juniperus growth amounts to less than two meters in most localities along the pipe line trench. Stratigraphical investigations further indicate that the sand and gravel which contains the Juniperus fragments were deposited some time before the Older Cover Sand I and the sediments underlying this unit are consequently older than the glaciation (Kolstrup, in press). This implies that very little, if any, sediment representing the melting of the Weichselian ice is present along this part of the gas pipe line trench.

Additional information concerning the geology of the Frøslev fan is given by Nielsen \& Sonnenborg (1982) who outline the geology along a pipe line trench between Frøslev and Gråsten in a technical report. The stretch they investigated starts near the Danish-German border at approximately the same site as the pipe line in fig. 2 and from this site it crosses the Frøslev fan (including some 4 to $5 \mathrm{~km}$ of the area within the eastern ice border line of Hansen (1965) in fig. 2) in a north-easterly direction.

In the area of the Frøslev alluvial fan these authors distinguish three subdivisions of the stretch: 1) Vilmkær-Frøslev (south-west), 2) Frøslev-Frøslev Kådnermark (a little more than one kilometer in the middle), and 3) Frøslev Kådnermark-Smedeby Mark (north-east). The descriptions of 1) and 3) are similar in that sand and gravel which is often involuted (cryoturbated) is present in the lower part of the profile and cover sand is found more or less continuously on the involuted. layer. Between Frøslev and Frøslev Kådnermark cover sand overlies diamict sediments of sandy and locally clayey materials which are interpreted as till (Nielsen \& Sonnenborg 1982).

As the area between Frøslev Kådnermark and Smedeby Mark contains the same sedimentary sequence and the same involuted horizon as found in the western part of the fan it seems reasonable to assume that this northwestern part has not been glaciated by the main Weichselian ice advance either.

This conclusion is in contradiction to the proposed position of the ice front of between less than one and about five kilometers to the east of the trench in fig. 2 .

If, however, the ice front was situated further to the east, outside or just touching the Frøslev alluvial fan this would be compatible with both 
the morphology and the stratigraphy of the fan. The till between Frøslev and Frøslev Kådnermark would consequently date from an earlier glaciation.

If the proposal of a more eastern ice front holds it implies new questions as to the time of formation of the fan, the source area of its sediments, and the conditions under which it formed.

\section{Conclusions}

The construction of the gas pipe line system in Denmark offers a unique opportunity to study the stratigraphy in all types of landscapes including areas in which open pits are absent. The Frøslev alluvial fan does not contain resource materials for construction purposes to such an extent that it is profitable to exploit it and open pits are therefore scarce. The stratigraphical outline and the geological considerations given above for the Frøslev fan are therefore based on observations for the gas pipe line trench alone.

In the trench the stratigraphical outline of fig. 3 has been established, and this outline together with the presence and the age of Juniperus wood fragments found at a somewhat lower level makes it possible to advance the idea that the Frøslev alluvial fan has probably not been influenced by meltwater streams from the Weichselian glacial maximum. Irregularities which can be ascribed to the presence of dunes are found in the 40 meters contour line of the fan. Apart from these irregularities the fan has a smooth, gently westward sloping face without major knickpoints or irregularities which might be ascribed to glacial advances, and the profiles in Nielsen \& Sonnenborg's report (1982) show that the sediments are principally the same on both sides of the suggested ice border line of the geological map (i.e., it seems that on the map Late Glacial fresh-water sand = glacial layered sand; LateGlacial fresh-water gravel = glacial layered gravel; eolian sand on Late-Glacial fresh-water sand = eolian sand on glacial layered sand). This, together with the absence of indications for meltwater streams which might be related to the glacial advance suggested by Hansen (1965), might mean that the fan has developed independantly of the Weichselian ice cap, that, in fact, most of the sediments in the Frøslev fan are older than the Middle Weichselian ice advance into the south Danish area.

During the maximum extension of the Weichselian ice the Frøslev fan may thus have been a periglacial area rather close to the ice front.

Acknowledgements. We want to express our gratitude to J. Stockmarr (Geological Survey of Denmark) for his critical perusal of the manuscript. H. H. Birks (Cambridge) kindly corrected the English text. The radio-carbon datings were carried out in the ${ }^{14} \mathrm{C}$-laboratory in Groningen, The Netherlands, under the guidance of W. Mook, and he and H. Tauber, Nationalmuseet, are thanked for valuable discussions concerning the datings. $\mathrm{K}$. Christensen, Nationalmuseet, was very helpful concerning information on the growth rings of Juniperus. T. Jensen, B. Jespersen, and J. Knudsen (Geological Survey of Denmark) have made the drawings, and $\mathrm{C}$. and I. Torres (Geological Survey of Denmark) skilfully took care of the photographical work. The Danish Oil and Natural Gas Company A/S (D.O.N.G. A/S) kindly gave permission to follow the trenching. The first author's investigation has been financed by the Geological Survey of Denmark and the Carlsberg Foundation. The Danish Natural Science Research Council (S.N.F.) financed the radio-carbon datings (grant no. 5.51.00.12).

\section{Dansk sammendrag}

I området omkring Frøslev i den sydlige del af Tinglev hedeslette udgør dæksande og fluviatilt sand og grus, der ofte er kryoturberet, de vigtigste sedimenttyper. Højdekurvekort over Tinglev hedeslette viser, at det danske område omkring Frøslev udgør en del af en selvstændig aflejringskegle, der her benævnes Frøslevkeglen (Frøslev alluvial fan).

Geologiske observationer under udgravningerne til naturgasledningen i 1981 har gjort det muligt at stykke den stratigrafi sammen, som er vist i fig. 3. I et stratigrafisk niveau et stykke under denne sekvens blev der over lange strak fundet stykker af enebærtræ, og det konkluderes, at enebærvaksten dateres til tiden mellem Brørup/Odderade interstadial(erne) og ca. 45.000 år før nu.

Trastykkerne, som findes $i$ alle størrelser op til $10 \times 4 \mathrm{~cm}$, forekommer som regel $i$ en fluviatil aflejring af sand og grus; men i to lokaliteter ser det ud til, at selve det daværende voksested er reprasenteret, og det er rimeligt at antage, at der en gang var enebarbevoksning på Frøslevkeglen.

Det ser ud til, at det kryoturberede lag lige under Frøslev gruslaget (Frøslev gravel bed i fig. 3) repræsenterer den kuldeperiode, som herskede, da isen nảede sin største udbredelse i den øvre del af Weichsel, og det er overraskende at konstatere, at der langs gasledningen tilsyneladende ikke findes smeltevandssedimenter, der kan relateres til denne is.

Denne mangel på smeltevandssedimenter samt keglens uforstyrrede morfologi tyder på, at isen og dens smeltevand ikke har påvirket Frøslevkeglens vesthældning under Weichselmaksimet. I stedet ser det ud til, at største delen af Frøslevkeglens sedimenter er ældre end hovedfremstødet, og at denne kegle har ligget som et periglacialt område uden for isranden. 


\section{References}

Andersen, S. T. 1961: Vegetation and its Environment in Denmark in the Early Weichselian Glacial (Last Glacial). Danmarks geologiske Undersøgelse, II Rk., Nr. 75, 175 pp.

Averdieck, F.-R. 1967: Die Vegetationsentwicklung des EemInterglazials und der Frühwürm-Interstadiale von Odderade/Schleswig-Holstein. Frühe Menschheit und Umwelt, II, Fundamenta B, 2, 101-125.

Doppert, J. W. C., Ruegg, G. H. J., van Staalduinen, C. J., Zagwijn, W. H. \& Zandstra, J. G. 1975: Lithostratigrafie. Formaties van het Kwartair en Boven-Tertiair in Nederland. In: W. H. Zagwijn \& C. J. van Staalduinen (eds.) Toelichting bij geologische overzichtskaarten van Nederland. Rijks geologische Dienst, 11-56.

Greguss, P. 1955: Xylotomische Bestimmung der heute lebenden Gymnospermen. Akadémiai Kiadó. Budapest. 308 pp.

van der Hammen, T. 1971: The Denekamp, Hengelo and Moershoofd Interstadials. In: T. van der Hammen \& T. A. Wijmstra (eds.) The Upper Quaternary of the Dinkel Valley. Mededelingen Rijks Geologische Dienst, N. S. 22, 81-85.

van der Hammen, T., Maarleveld, G. C., Vogel, J. C. \& Zagwijn, W. H. 1967: Stratigraphy, Climatic Succession and Radiocarbon Dating of the Last Glacial in The Netherlands. Geologie en Mijnbouw, 46 (3), 79-95.

Hansen, S. 1965: Kortbladet Tinglev, 1:100.000. Danmarks geologiske Undersøgelse, I, 23A.

Houmark-Nielsen, M. \& Kolstrup, E. 1981: A radiocarbon dated Weichselian sequence from Sejerø, Denmark. Geologiska Föreningens i Stockholm Förhandlingar, 103, 1, 73-78.

Jessen, K. \& Milthers, V. 1928: Stratigraphical and Paleontological Studies of Interglacial Fresh-water Deposits in Jutland and Northwest Germany. Danmarks geologiske Undersøgelse, II, 48, $379 \mathrm{pp}$.

Kihlman, A. O. 1890: Pflanzenbiologische Studien aus Russisch Lappland. Acta Societatis Pro Fauna et Flora Fennica. VI, 3, 263 pp.

Kolstrup, E. (in press): Cover Sands in southern Jutland (Denmark). Fourth International Conference on Permafrost, Proceedings, Volume I.
Kolstrup, E. \& Jørgensen, J. B. 1982: Older and Younger Coversand in southern Jutland (Denmark). Bulletin of the geological Society of Denmark, 30, 71-77.

Kolstrup, E. \& Wijmstra, T. A. 1977: A palynological investigation of the Moershoofd, Hengelo, and Denekamp Interstadials in The Netherlands. Geologie en Mijnbouw, $56,85-102$.

Lykke-Andersen, A.-L. 1981: En ny C-14 datering fra Fldre Yoldia Ler i Hirtshals Kystklint. Dansk geologisk Forening. Arsskrift for 1980. 1-5.

Mamakowa, K., Mook, W. G. \& Srodoń, A. 1975: Late Pleistocene Flora at Katy (Pieniny Mts., West Carpathians). Acta Palaeobotanica, XVI (2), 147-172.

Menke, B. 1976: Neue Ergebnisse zur Stratigraphie und Landschaftsentwicklung im Jungpleistozän Westholsteins. Eiszeitalter und Gegenwart. 27, 53-68.

Milthers, V. 1948: Det danske Istidslandskabs Terrænformer og deres Opstaaen. Danmarks geologiske Undersøgelse, III, $28,223 \mathrm{pp}$.

Nielsen, M. B. \& Sonnenborg, A. 1982: Teknisk rapport over de geologiske undersøgelser ved nedgravningen af naturgasledningen Frøslev-Gråsten. Naturforvaltningsprojekt. Teknisk Forvaltning. Sønderjyllands Amtsråd. 35 pp.

Odgaard, B. V. 1982: A Middle Weichselian moss assemblage from Hirtshals, Denmark, and some remarks on the environment 47,000 B. P. Danmarks geologiske Undersøgelse, Årbog 1981, 5-45.

Schmidt, E. 1941: Mikrophotographischer Atlas der mitteleuropäischen Hölzer. Schriftenreihe Reichsinst. kolon. Forstwirtschaft, 1, Neumann, Neudamn. 112 pp.

Zagwijn, W. H. 1961: Vegetation, Climate and Radiocarbon Datings in the Late Pleistocene of the Netherlands. I: Eemian and Early Weichselian. Memoir of the Geological Foundation in the Netherlands, N. S. 14, 15-45.

Zagwijn, W. H. 1974: Vegetation, climate and radiocarbon datings in the Late Pleistocene of The Netherlands. II: Middle Weichselian. Mededelingen Rijks Geologische Dienst, N. S. 25, 3, 101-110. 